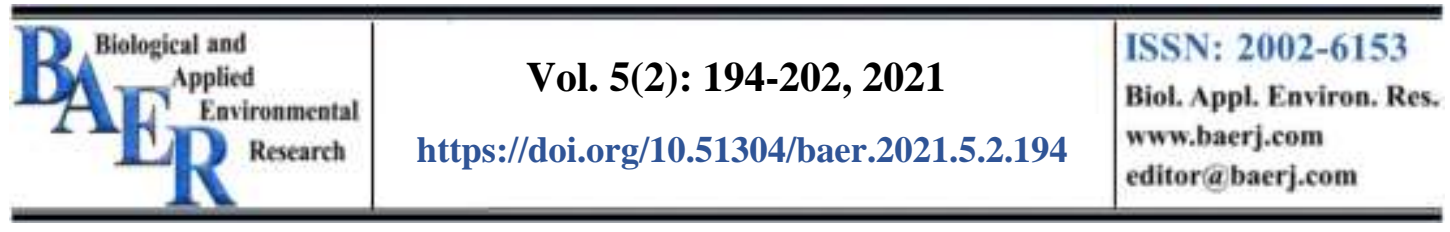

\title{
Water Quality Assessment of Shatt Al-Arab River, Southern Iraq Using NSF-WQI
}

\author{
Ali W. Ali ${ }^{*} \&$ Amjed K. Resen ${ }^{2}$ \\ ${ }^{1}$ Department of Marine Vertebrates, Marine Sciences Center, University of Basrah, Iraq \\ ${ }^{2}$ Department of Fisheries and Marine Resources, College of Agriculture, \\ University of Basrah, Iraq \\ *Corresponding author: ali79wafeeq@gmail.com
}

\begin{abstract}
Three stations were selected on Shatt Al-Arab River, which is distinguished by its fresh water that is used for drinking, agriculture and industry. The first station is located in the north of Basrah Province in AlShafy, the second in the province center in Al-Salhiya and the third one to the south in the Sahel Region, during the period from October 2019 until September 2020. The study aimed to assess the quality of Shatt Al-Arab River water by using the NSF-WQI guide and its suitability for various uses as it represents an easy and efficient method of evaluation. Seven factors were used in the study: dissolved oxygen, biochemical oxygen demand, reactive phosphate, potential of Hydrogen, total dissolved solids, nitrates and water temperature. The results showed that the water quality index values varied between 110-122, as Shatt Al-Arab River water is generally classified as poor water. The second station recorded the highest (122) value for the index, while the first station recorded the lowest value (110).
\end{abstract}

Keyword: Shatt Al-Arab River, Water quality, NSF-WQI

\section{Introduction}

Shatt Al-Arab River is one of the main and important rivers in Iraq and the main source of fresh surface water in Basrah Province which is used for drinking, irrigation, navigation, fisheries and industry (Abdullah et al., 2015).

Shatt Al-Arab River suffers from a decrease in the quality of water, especially in recent years, due to the low rate of water drainage in the Tigris and Euphrates rivers as a result of the construction of many dams in the headwaters of the main rivers in Turkey (Partow, 2001).

Water quality can be described as the chemical, physical and biological characteristics of water that are related to its suitability for a specific use, such as for drinking, agriculture, livestock or entertainment. These uses, despite the existence of common requirements, remain with their own requirements and the deterioration of water sources. It has negative effects not only on biological diversity, but also as an indicator of the deteriorating health status of the environment (Roy, 2019). 
The water quality index provides a single number that gives a clear and integrated picture of the overall quality of the water situation at a specific time and location from studying a set of factors affecting water quality. The main goal is to convert complex data into information that is easy to understand, interpret and use (Charuvan et al., 2012).

In 1970, the Water Quality Index (Wqi) was developed by the National Sanitation Foundation by taking the opinions of 142 scientists from water scientists after studying 35 factors, in order to subsequently choose nine factors in the computation of the index (Sharifi, 1990). The NSF-WQI index was applied locally by Farhood (2016), Hamdan et al. (2018) and Al-Hamdany et al. (2020) and assessed the water quality of Shatt Al-Arab River.

The present study aimed at knowing the temporal and spatial changes of the water quality variables and thus applying the NSF-WQI guide as an efficient way to assess the water quality of the Shatt al-Arab.

Water Quality Index (NSF-WQI) guide is considered as one of the global evidence that is widely used in evaluating water quality, by giving a weight to each of the studied factors, which is reflected in the increase in the accuracy of the results of the guide in its evaluation of water quality by giving one value that expresses this quality and thus it becomes easy to know the suitability of this water for a specific use (Sharifinia et al., 2019; Al-Hamdany et al., 2020).

\section{Materials and Methods \\ Study Area}

Shatt Al-Arab River is located in the south of Iraq, which consists of the confluence of the Tigris and Euphrates rivers in Qurna city. Its length is about 195 $\mathrm{km}$ and extends southeastward along the city of Basrah, through the ports of Abu Flus (in Iraq) and Abadan (in Iran) to the city of Faw and from there it extends approximately $18 \mathrm{~km}$ until it flowing toward the Arabian Gulf (Fig. 1). The southern part of Shatt Al-Arab River suffers from tidal phenomenon as a result of the entry of the Gulf waters to it, so that the quality of the downstream water becomes mixed between marine and fresh (Abdullah et al., 2015). The size of Shatt Al-Arab River basin forms an area estimated at about $884,000 \mathrm{~km}^{2}$. The width of this river decreases from $232 \mathrm{~m}$ in the center of Basrah city to $800 \mathrm{~m}$ at the mouth of the river (Gatea, 2018). Throughout this distance from its confluence to the estuary, the quality of its water is affected by many activities on its banks, represented by the presence of many agricultural and tributaries that drain their water directly or indirectly to the river with what it carries all kinds of pesticides and fertilizers, and exposed to throwing wastes from some factories such as the paper mill and power plants, as well as the resulting industrial or thermal wastes. The unloading and loading platforms for goods represented in the port of Maqal and the rest of the ports are also located on both banks of the river has groups of inhabitants that practice many professions, including raising animals such as buffaloes and species of birds, all of which add to the burden of polluting its waters, as well as sewage wastes that are thrown directly into Shatt Al-Arab River 
without treatment, as indicated by Al-Hejuje (2014) who showed that Shatt AlArab River is one of the rivers, which are polluted with various pollutants, including organic matter, which resembles other polluted rivers in the world. The region is characterized by its hot climate and north to northwestern winds with the blowing of dust storms. The region is characterized by a very hot summer season, where air temperature sometimes reaches $50{ }^{\circ} \mathrm{C}$ (Eassa \& Mahmood, 2012).
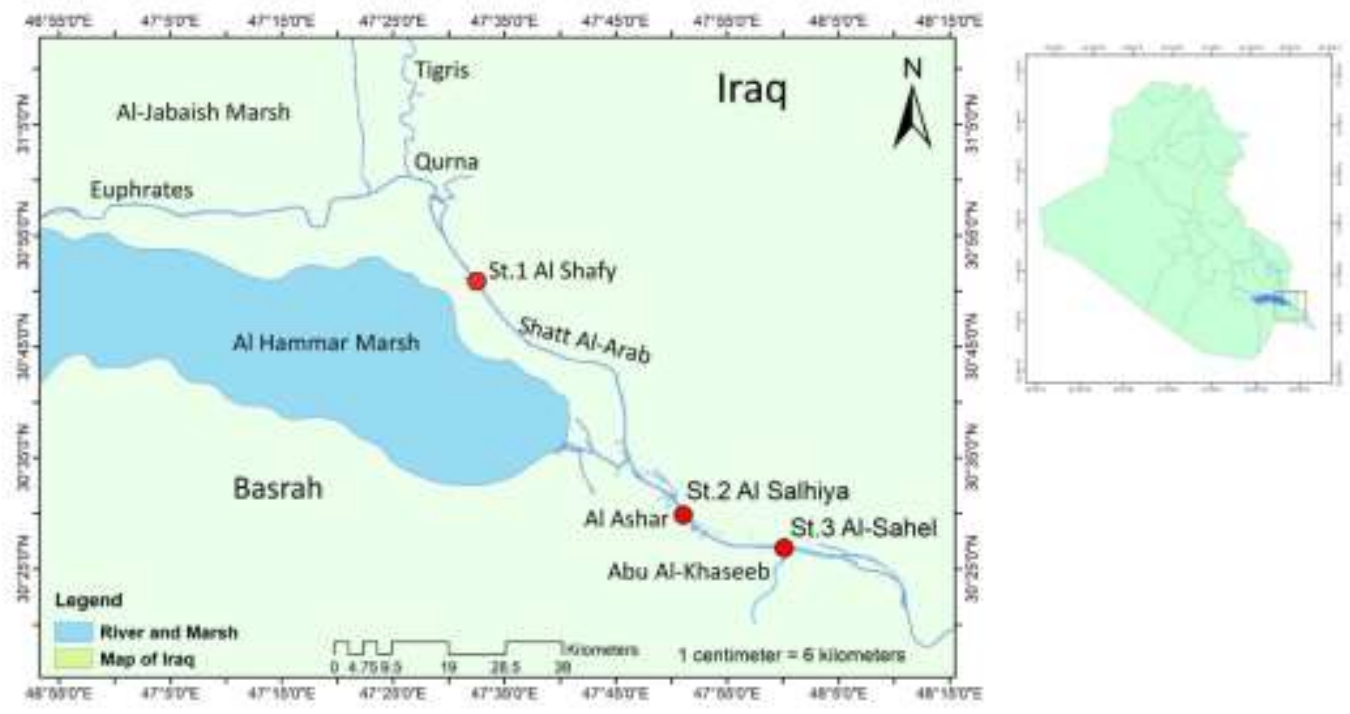

Figure 1: Map of Shatt Al-Arab River with locations of study sites.

\section{Collecting Samples}

Three stations were selected on Shatt Al-Arab River: the first station represented control due to its location north of Basrah, somewhat far from pollutants. The second and third were chosen in this way to cover the largest possible section of the Shatt al-Arab and to be located in residential and agricultural areas in which there are many pollutants to collect samples for the period from October 2019 to September 2020, with one sample at the time of ebb for each station per month by using $500 \mathrm{ml}$ polyethylene bottles for the purpose of conducting the tests. Table 1 shows the names and coordinates of these three stations.

Table 1: Names of the studied stations and their coordinates.

\begin{tabular}{|l|c|c|c|}
\hline \multicolumn{1}{|c|}{ Station } & Name & Latitude & Longitude \\
\hline St. 1 & Al-Shafy & $47^{\circ} 32^{\prime} 30.8336^{\prime \prime} \mathrm{E}$ & $30^{\circ} 50^{\prime} 52.9145^{\prime \prime} \mathrm{N}$ \\
\hline St. 2 & Al-Salhiya & $47^{\circ} 51^{\prime} 3.2138^{\prime \prime} \mathrm{E}$ & $30^{\circ} 29^{\prime} 52.178^{\prime \prime} \mathrm{N}$ \\
\hline St. 3 & Al-Sahel & $48^{\circ} 0^{\prime} 6.9836^{\prime \prime} \mathrm{E}$ & $30^{\circ} 26^{\prime} 52.8539^{\prime \prime} \mathrm{N}$ \\
\hline
\end{tabular}




\section{Field and Laboratory Work}

Water temperature (WT) was measured in the field by using a graded mercury thermometer $\left(0.1-100{ }^{\circ} \mathrm{C}\right)$. Measuring the $\mathrm{pH}$ of water in a field was by using a German-made (PH 3110 WTW) device after calibrating the device with buffer solutions (4, 7 and 9). US-made YSI model 556MPS was used for measuring total dissolved solids (TDS) in mg/l. Both dissolved oxygen (DO) and biochemical oxygen demand (BOD 5 ) were laboratory measured according to APHA (2005) in $\mathrm{mg} / \mathrm{l}$. Reactive phosphates $\left(\mathrm{PO}_{4}\right)$ were measured by using the method of Murphy \& Riley (1962) in $\mu \mathrm{g} / \mathrm{l}$, and as for nitrates $\left(\mathrm{NO}_{3}\right)$ in $\mu \mathrm{g} / \mathrm{l}$ by a method of Parsons et al. (1984).

\section{Water Quality Index}

In this study, NSF-WQI was used as it is an easy tool to express water quality in one appropriate or inappropriate word by summarizing a large number of data in one number. Seven environmental factors were used because it is considered as one of the important factors in evaluating the quality of river water, and because it is among the factors that are included in the calculation of the index values: DO, $\mathrm{BOD}_{5}, \mathrm{PO}_{4}, \mathrm{pH}, \mathrm{TDS}, \mathrm{NO}_{3}$ and $\mathrm{WT}$. The value of the guide was calculated based on the environmental determinants of the Iraqi river conservation system for the year 2011 and US-EPA 2012, according to the guide based on Ramakrishnaiah et al. (2009) and Al-Hejuje (2014).

NSFWQI $=\sum W i$ Qi

$\mathrm{Wi}$ : According to the weight to the relative importance of each of the water quality factors in the guide. This weight ranges between 1-4, give 4 for each of DO, and $\mathrm{BOD}_{5}, 3$ for $\mathrm{PO}_{4}, 2$ for each of the $\mathrm{pH}$, TDS and $\mathrm{NO}_{3}$ while 1 for WT.

Table 2: The relative weight of the factors involved in the calculation of NSF-WQI.

\begin{tabular}{lcc}
\hline \multicolumn{1}{r}{ Parameter } & Weight (wi) & Relative weight (Wi) \\
\hline $\mathrm{DO}$ & 4 & 0.222222222 \\
$\mathrm{BOD}_{5}$ & 4 & 0.222222222 \\
$\mathrm{PO}_{4}$ & 3 & 0.166666667 \\
$\mathrm{pH}$ & 2 & 0.111111111 \\
$\mathrm{TDS}$ & 2 & 0.111111111 \\
$\mathrm{NO}$ & 2 & 0.111111111 \\
W.T. & 1 & 0.055555556
\end{tabular}

$$
\mathrm{Qi}=\sum \frac{\mathrm{Vi}}{\mathrm{Si}} \times 100 \text { (Parsons et al., 1984) }
$$

The sub-index Qi is calculated according to Sirajudeen \& Abdul Vahith (2014) where $v i=$ measured value of factors and $\mathrm{si}=$ standard value of factors. 
Table 3: Water classification standards according to the NSF-WQI index values (AlHejuje, 2014).

\begin{tabular}{|l|c|c|c|c|c|}
\hline \multicolumn{1}{|c|}{ Category } & A & B & C & D & E \\
\hline NSF-WQI score & $<50$ & $50-100$ & $100-200$ & $200-300$ & $>300$ \\
& & & & & \\
\hline Description & Excellent & Good & Poor & Very poor & Unsuitable \\
\hline
\end{tabular}

\section{Results and Discussion}

Table 4 shows the highest, lowest, average and standard deviation of the water quality variables from October 2019 to September 2020 in the three study stations.

Table 4: Statistical analysis of environmental factors data in the study stations.

\begin{tabular}{lcccccccc}
\hline Station & Static & DO & $\mathrm{BOD}_{5}$ & $\mathrm{PO}_{4}$ & $\mathrm{pH}$ & $\mathrm{TDS}$ & $\mathrm{NO}_{3}$ & W.T. \\
\hline \multirow{5}{*}{ St 1} & Min. & 4.80 & 1.40 & 0.02 & 7.26 & 1.06 & 0.18 & 13.40 \\
& Max. & 11.80 & 5.0 & 0.75 & 8.67 & 4.07 & 7.40 & 28.84 \\
& Mean & 7.28 & 3.10 & 0.30 & 7.91 & 2.11 & 3.54 & 21.59 \\
& SD & 2.66 & 1.12 & 0.28 & 0.39 & 0.83 & 2.57 & 5.82 \\
\hline \multirow{5}{*}{ St 2} & Min. & 4.47 & 2.10 & 0.02 & 7.39 & 1.55 & 0.50 & 13.05 \\
& Max. & 11.20 & 5.40 & 0.95 & 8.32 & 3.07 & 8.96 & 31.20 \\
& Mean & 7.0 & 3.88 & 0.32 & 7.91 & 2.53 & 4.60 & 22.90 \\
& SD & 2.48 & 1.01 & 0.37 & 0.27 & 0.46 & 2.93 & 6.40 \\
\hline \multirow{5}{*}{ St 3 } & Min. & 4.36 & 1.70 & 0.02 & 7.06 & 2.04 & 0.65 & 13.53 \\
& Max. & 10.20 & 5.20 & 0.64 & 8.41 & 3.97 & 7.66 & 32.00 \\
& Mean & 7.28 & 3.47 & 0.20 & 8.05 & 2.29 & 3.71 & 22.92 \\
& SD & 2.37 & 1.12 & 0.22 & 0.37 & 1.46 & 2.47 & 6.82 \\
\hline
\end{tabular}

The above table shows that the highest oxygen value $(11.80 \mathrm{mg} / \mathrm{l})$ was recorded in the first station and the lowest $(4.36 \mathrm{mg} / \mathrm{l})$ in the third station. The increase in oxygenation was observed during the cold months, and the reason for this increase may be due to an increase in the solubility of oxygen due to the decrease in temperature that accompanied it. A decrease in the decomposition of organic matter that consumes oxygen, as the solubility of gases is inversely proportional to the temperature, was observed, and it may be attributed to the decrease in oxygen concentration. During the summer months, evaporation increases due to the high temperature and the resulting decomposition of organic materials that consume oxygen, especially in the second and third stations, which may receive untreated wastewater due to its proximity to residential areas where microorganisms, oxidize organic materials using oxygen and thus, decrease its value (Moyel \& Hussain, 2015).

The highest values of $\mathrm{BOD}_{5}$ for water $(5.40 \mathrm{mg} / \mathrm{l})$ were recorded in the second station and the lowest $(1.40 \mathrm{mg} / \mathrm{l})$ in the first station. In the analysis of organic matter, its decrease in winter coincides with the decrease in temperature, which results from the lack of activity of microorganisms (Ahmed, 2017).

The value of $\mathrm{PO}_{4}$ ranged between the highest value $(0.95 \mathrm{mg} / \mathrm{l})$ in the second station and $0.02 \mathrm{mg} / \mathrm{l}$ for all stations. The highest values were recorded during the 
period from April to August for all stations, which may be due to low levels of river drainage on some days of the year, and the increase in pollutants carried by the subsidiary rivers from washing powders that are rich in phosphate compounds or sewage water that are discarded without treatment or from drainage water from agricultural and industrial wastes containing phosphate fertilizers (Al-Hejuje, 2014). The reason for the decrease in concentrations may be due to the period from November through February which indicates consumption by phytoplankton and plants that have a tendency to accumulate phosphates in their tissues (Moyel \& Hussain, 2015) or, it may be due to adsorption to the surfaces of organic compounds and soil minerals in sediments (Weiner, 2000).

The highest water $\mathrm{pH}$ values were recorded in the first station (8.67) and the lowest (7.06) in the third station, as it was within the weak baseline trend throughout the study period, due to the high regulatory capacity of Iraqi waters due to its high content of carbonates and bicarbonates (Stirling, 1985). The $\mathrm{pH}$ rise was observed during the hot months from June to September, especially in the third station, where the height was consistent with the high salinity and total dissolved solids, especially in the third station. The reason may be due to the increase in the concentrations of salts and dissolved solids during these months and the entry of sea water bicarbonate-bearing saline, as it has also been shown by Al-Hejuje (2014). The high pH of the water of Shatt Al-Arab River in the basal direction was as a result of entering the salty front from the Gulf and the decrease in water discharges in Shatt Al-Arab River, which results in an increase in the concentration of dissolved substances in the water. This helps to lower the $\mathrm{pH}$ (Al-Lami et al., 2001).

The values of TDS in the study stations showed that the highest values (4.07 $\mathrm{mg} / \mathrm{l})$ was in the first station and the lowest value $(1.06 \mathrm{mg} / \mathrm{l})$ for the same station. It was observed that the concentrations of total dissolved solids increased during winter and spring months. This may be attributed to the runoff of water and discarded water, in addition to sewerage, which adds solids to the water and increases its concentration (Al-Hejuje, 2014). TDS values decreased during June and July, especially in the first station. This may be due to the high discharges of water coming from Tigris River, or it may be due to the location of this station north of Basrah and its distance from the tidal effects and its receipt of small quantities of dissolved solids and organic materials (Al-Mansouri \& Al-Mahmoud, 2009).

The nitrates recorded the highest value $(8.96 \mathrm{mg} / \mathrm{l})$ in the second station and the lowest $(0.18 \mathrm{mg} / \mathrm{l})$ in the first station. Nitrate concentrations increased during the cold months from December to April. This increase may be attributed to the rain that works to dissolve organic materials and compounds nitrogen levels in fertilized agricultural and industrial wastes and their entry into Shatt Al-Arab River waters (Moyel \& Hussain, 2015). This may be attributed to the high levels of dissolved oxygen at low temperatures that stimulate micro-organisms to oxidize ammonia to nitrates, as a positive direct correlation was found between nitrates and dissolved 
oxygen $(r=0.491)$. The second station showed a remarkable increase during months of the year. This may be attributed to the station's proximity to residential areas, the decrease in water drainage and the increase in the percentage of pollutants released directly or through branches of the rivers that flow into Shatt Al-Arab River and carrying industrial and household wastes and untreated wastewater loaded with nitrogenous compounds that are oxidized to nitrates (AlHejuje, 2014). The decrease in values during the period from September to November may be attributed to the increase in phytoplankton activity and nitrateconsuming aquatic plants, as this is consistent with the findings of Moyel \& Hussain (2010).

The water temperature showed clear changes between summer and winter seasons, as it recorded the highest value $\left(32^{\circ} \mathrm{C}\right)$ in the third station, then began to decrease until it recorded the lowest temperature $\left(13.05{ }^{\circ} \mathrm{C}\right)$ in the second station. This difference may be due to the differences in temperature between summer months, which are characterized by the long period of the day, the increase in the brightness of the sun and the angle of its fall. Winter months are characterized by the shortness of the day and the weakness of the solar radiation. This difference is also attributed to the nature of the climate in Iraq, as it is cold and rainy in winter and hot and dry in summer (Al-Hejuje, 2014).

\section{Conclusion}

The results of the environmental factors analysis showed that Shat Al-Arab River water is classified as poor water according to the index classification (NSFWQI), where the index value was 117 . It was noticed that there was little discrepancy between the indexes values of the three stations recorded. The second station has the highest value of the guide (122), followed by the third station (117) and the first station (110). The reason for the decrease in the index values and the deterioration of the quality of Shatt Al-Arab River water in general, according to this guide, may be due to an increase in concentrations of $\mathrm{BOD}_{5}, \mathrm{PO}_{4}, \mathrm{TDS}$ and $\mathrm{NO}_{3}$, especially in the second station in which the index value was the highest (122) compared to the other two stations. The results of the study were consistent with Al-Hejuje (2014).

\section{References}

Abdullah, A.D.; Masih, I.; van der Zaag, P.; Karim, U.F.A.; Popescu, I. \& Al Suhail, Q. (2015). Shatt Al Arab River system under escalating pressure: A preliminary exploration of the issues and options for mitigation. Int. J. River Basin Manage., 13(2): 215-227. DOI:10.1080/15715124.2015.1007870.

Ahmed, M.H. (2017). Structual of small fish assemblage at nursury areas and effect of organic pollution in Garmat Ali River, Basrah/ Iraq. M. Sc. Thesis, Coll. Agric., Univ. Basrah: 85 pp. (In Arabic).

Al-Hamdany, N.A.S.; Al-Shaker, Y.M.S. \& Al-Saffawi, A.Y.T. (2020). Water quality assessment using the NSFWQI model for drinking and domestic 
purposes: A case study of groundwater on the left side of Mosul city, Iraq. Plant Arch., 20(1): 3079-3085.

Al-Hejuje, M.M.K. (2014). Application of water quality and pollution indices to evaluate the water and sediments status in the middle part of Shatt Al-Arab River. Ph. D. Thesis. Coll. Sci., Univ. Basrah: 239 pp.

Al-Lami, A.A.; Sabri, A.W.; Mohsen, K.A. \& Al-Dulymi, A.A. (2001). Ecological effects of the Tharthar arm on Tigris River: Physical and chemical parameters. Sci. J. Iraqi At. Energy Comm., 3(2): 122-136. (In Arabic).

Al-Mansouri, F.Y. \& Al-Mahmoud, H.K.H. (2009). Al-Ezz River and its effect on the river load of the Shatt Al-Arab. Univ. Thi-Qar J., 4(4): 113-121. (In Arabic).

APHA, American Puplic Health Association (2005). Standard methods for the examination of water and wastewater. $21^{\text {st }}$ edition, Washington, DC: $733 \mathrm{pp}$.

Charuvan, K.; Senee, S. \& Vipavee, A. (2012). Water quality index of San Saeb Canal. $4^{\text {th }}$ Int. Sci., Soc. Sci., Eng. Energy Conf., 11-14 Dec. 2012, Petchburi, Thailand: 404-408.

Eassa, A.M. \& Mahmood, A.A. (2012). An assessment of the treated water quality for some drinking water supplies at Basrah. J. Basrah Res. (Sci.), 38(3A): 95105.

Farhood, A.T. (2016). Water quality status in different aquatic environments in Thi-Qar Province based on NSF-WQI. J. Thi-Qar Sci., 6(1): 17-24.

Gatea, M.H. (2018). Study of water quality changes of Shatt Al-Arab River, South of Iraq. J. Univ. Babylon Eng. Sci., 26(8): 228-241.

Hamdan, A.; Dawood, A. \& Naeem, D. (2018). Assessment study of water quality index (WQI) for Shatt Al-Arab River and its branches, Iraq. MATEC Web Conferences, 162, 05005: 1-7. DOI:10.1051/matecconf/201816205005.

Moyel, M.S. \& Hussain, N.A. (2015). Water quality assessment of the Shatt AlArab River, Southern Iraq. J. Coast. Life Med., 3(6): 459-465.

Murphy, J. \& Riley, J.P. (1962). A modified single solution method for the determination of phosphate in natural waters. Anal. Chim. Acta, 27(C): 3136. DOI:10.1016/S0003-2670(00)88444-5.

Parsons, T.R.; Matia, Y. \& Lalli, C.M. (1984). A manual of chemical and biological methods for sea water analysis. Pergamon Press. Oxford: $360 \mathrm{pp}$.

Partow, H. (2001). The Mesopotamian marshlands: Demise of an ecosystem. Early warning and assessment technical report, UNEP/DEWA, Nairobi. http://www.grid.unep.ch/product/publication/download/ mesopotamia.pdf.

Ramakrishnaiah, C.R.; Sadashivaiah, C. \& Ranganna, G. (2009). Assessment of water quality index for the groundwater in Tumkur Taluk, Karnataka State, India. E-J. Chem., 6(2): 523-530. DOI:10.1155/2009/757424.

Roy, R. (2019). An introduction to water quality analysis. ESSENCE Int. J. Env. Rehab. Conserv., 9(1): 94-100. DOI:10.31786/09756272.18.9.2.214.

Sharifinia, M.; Ramezanpour, Z.; Imanpour, J.; Mahmoudifard, A. \& Rahmani, T. (2019). Water quality assessment of the Zarivar Lake using physico-chemical parameters and NSF-WQI indicator, Kurdistan Province- Iran. Int. J. Adv. 
Biol. Biomed. Res., 7(1): 87-97.

Sharifi, M. (1990). Assessment of surface water quality by an index system in Anzali basin. The Hydrobiological Basis for Water Resources Management. Proc. Beijing Symp., October 1990. IAHS Publ. No. 197: 163-171.

Sirajudeen, J. \& Abdul Vahith, R. (2014). Applications of water quality index for groundwater quality assessment on Tamil Nadu and Pondicherry, India. J. Environ. Res. Dev., 8(3): 443-450.

Stirling, H.P. (ed.) (1985). Chemical and biological methods of water analysis for aquaculturists. Univ. Sterling: 199 pp.

Weiner, E.R. (2000). Application of environmental chemistry: A practical guide for environmental professionals. Lewis Publ., Boca Raton, New York: 276 pp. 